\title{
Investigating brand romance, brand attitude and brand loyalty in the cellphone industry
}

\author{
Authors: \\ Liezl-Marié Kruger \\ Stefanie W. Kühn ${ }^{1}$ \\ Daniel J. Petzer \\ Pierre G. Mostert ${ }^{1}$

\section{Affiliations:} \\ ${ }^{1}$ Workwell Research Unit for \\ Economic and Management \\ Sciences, North-West \\ University, South Africa \\ Correspondence to: \\ Daniel Petzer \\ Email: \\ 11196092@nwu.ac.za \\ Postal address: \\ Private Bag X6001, \\ Potchefstroom 2520, \\ South Africa \\ Dates: \\ Received: 13 Feb. 2013 \\ Accepted: 31 July 2013 \\ Published: 16 Sept. 2013 \\ How to cite this article: \\ Kruger, L-M., Kühn, S.W., \\ Petzer, D.J. \& Mostert, P.G. \\ 2013, 'Investigating brand \\ romance, brand attitude \\ and brand loyalty in the \\ cellphone industry', Acta \\ Commercii 13(1), Art. \#178, \\ 10 pages. http://dx.doi. \\ org/10.4102/ac.v13i1.178

\section{Copyright:} \\ (C) 2013. The Authors. \\ Licensee: AOSIS \\ OpenJournals. This work \\ is licensed under the \\ Creative Commons \\ Attribution License.
}

Read online:
Orientation: Fast growth and intense competition characterise the South African cellphone industry. Customers switch easily between cellphone brands and marketers are challenged to cultivate brand relationships with customers in order to ensure brand loyalty.

Research purpose: This study investigated the brand romance, -attitude and -loyalty of customers toward their cellphone brands in the North West Province, South Africa.

Motivation for the study: One way in which brand loyalty in the cellphone industry can be achieved is to influence attitudes and, ultimately, create brand loyalty by promoting brand romance between the customer and the brand.

Research design, approach and method: Being quantitative in nature, the study followed a descriptive research design to collect 371 responses through self-administered questionnaires.

Main findings: The results indicated that most respondents were contract customers who only use a brand of cellphone for between one and three years. Brand romance toward cellphone brands was positive although room for improvement exists. Brand attitude toward current cellphone brands was also positive, but brand loyalty was fairly low, indicating that marketers need to improve brand loyalty toward their cellphone brand. There were, furthermore, significant and positive relationships between brand romance, brand attitude and brand loyalty toward cellphone brands.

Practical/managerial implications: Brand romance can be considered to be a viable way of improving attitude toward a cellphone brand, ultimately leading to brand loyalty.

Contribution/value-add: Brand romance in brand relationships has significant and positive relationships with brand attitude and brand loyalty in the cellphone industry of South Africa.

\section{Introduction}

The fast-developing cellphone industry, where handsets improve constantly, necessitates the forging of consumer-brand relationships (Franzak \& Pitta 2011:396) in order to keep consumers brand loyal and thus prevent them from switching to competing brands (Hoyer, MacInnis \& Pieters 2013:252; Wang \& Li 2012:149). 'Cellphone brands' refers, in essence, to the brands with which handsets are identified, such as Nokia, Samsung and BlackBerry, to name but a few (Fripp 2012).

The emotional attachments that consumers foster with brands are important to marketers who wish to establish long-term relationships with their consumers (Long-Tolbert \& Gammoh 2012:391). Although emotional attachment has been investigated by numerous authors (Belaid \& Behi 2011:38; Hwang \& Kandampully 2012:103; Mugge, Schifferstein \& Schoormans 2010:271), emotional attachment in terms of brand romance, as proposed by Patwardhan and Balasubramanian (2011:299), merits further investigation, specifically within the cellphone industry (Wang \& Li 2012:164, 170).

Brand romance is of importance considering that it enhances attitudinal loyalty (Aurier \& De Lanauze 2011:823) and may predict brand loyalty better than brand attitude (Patwardhan \& Balasubramanian 2011:304). If brand romance influences brand attitude and brand loyalty, cellphone brands can create, as a means to obtain a competitive advantage, strategies fostering brand romance in order to build brand loyalty. In instances where consumers see their brand in the same way as a romantic partner (as with brand romance), relationships are less expensive to retain and more profitable in the long run for marketers (Hess, Story \& Danes 2011:14).

This paper investigates brand romance, brand attitude and brand loyalty toward cellphone brands and also considers whether differences exist between consumers based on demographics and cellphone-patronage habits with respect to these constructs. In the following section, a theoretical 
background for the study is presented. Subsequently, the problem statement, purpose and objectives, research methodology, findings of the research and discussion follow. Finally, limitations and future research conclude this paper.

\section{Literature background The cellphone industry of South Africa}

The South African cellphone industry has been characterised by major growth and is regarded as being one of the fastestgrowing industries on the African continent (Sibanda 2008; SouthAfrica.info 2012). The number of cellphone users has more than doubled from 12 million in 2005 to 28 million in 2011, constituting $82 \%$ of the adult South African population (South African Advertising Research Foundation 2012).

Competition between cellphone brands has also increased as a variety of different cellphone handsets and smart phones have started entering the South African market, making them accessible and affordable to South African consumers, as well as making it easier to switch between brands (Berger, Sinha \& Pawelczyk 2012; Tubbs 2012). Marketers therefore need to broaden their understanding of how consumers interact and form emotional attachments with their brands in order to foster brand loyalty (Patwardhan \& Balasubramanian 2011:299).

\section{Brand romance}

Patwardhan and Balasubramanian (2011:299) have defined brand romance as an emotional attachment; an attraction not yet developed into brand love. Although brand love has been examined by different authors (Hwang \& Kandampully 2012:103; Ismail \& Spinelli 2012:387; Long-Tolbert \& Gammoh 2012:398), the pre-existing stage of the consumer-brand relationship, brand attachment in terms of brand romance, has not been explored in such detail. Brand romance has three dimensions, namely pleasure, arousal and dominance (Patwardhan \& Balasubramanian 2011:299).

Emotional attachment and consumer-brand relationships start with consumers experiencing pleasure (Li, Dong \& Chen 2012:136; Mugge et al. 2010:279; Patwardhan \& Balasubramanian 2011:299). The association of positive feelings with the brand was labelled by Patwardhan and Balasubramanian (2011:299) as 'pleasure'. When these positive feelings are intense enough to arouse the consumer in a meaningful or effective way, the second dimension of brand romance - arousal - is considered to be at play (Patwardhan \& Balasubramanian 2011:299). Pleasure and arousal have a direct influence on consumers' actual purchase behaviour ( $\mathrm{Li}$ et al. 2012:135). Lastly, dominance refers to the tendency of the brand to engage the consumers' cognition (Patwardhan \& Balasubramanian 2011:299).

An emotional attachment or affective commitment (such as brand romance in terms of an attraction) enhances attitudinal loyalty (Aurier \& De Lanauze 2011:823) and thus brand loyalty (Hwang \& Kandampully 2012:103). Brand romance as attraction is considered to be a progression beyond a positive attitude (Patwardhan \& Balasubramanian 2011:299).

\section{Brand attitude}

An attitude can be considered to be a relative, enduring, context-specific overall evaluation of some aspects of a consumer's environment, be it a product, service or brand (Hoyer et al. 2013:128; Petruzzellis 2010:615; Solomon 2013:273). Therefore, brand attitude can be described as being a consumer's overall evaluation of the ability of the brand to satisfy needs (Liu et al. 2012:924).

Fishbein (1963:238), as well as Wilkie and Pessemier (1973:428), proposed multi-attribute attitude models where consumers' beliefs regarding the brand would be rated in terms of attributes in order to form overall evaluations of brands. However, Bagozzi et al. (1979:92-93) posited that attitudes consist of different content dimensions labelled as affective-, behavioural- and cognitive dimensions. As proposed by $\mathrm{Wu}$ and Wang (2011:453, 457), this study views brand affection, purchase intention and brand trust as presenting the affective-, behavioural- and cognitive dimensions of brand attitude respectively. Due to the definitional overlap between behavioural brand loyalty (Belaid \& Behi 2011:39) and brand purchase intention (Wu \& Wang 2011:453, 457), brand attitude was only measured in terms of brand affection and brand trust. In conclusion, consumers' attitudes predict their purchase intention and behaviour (Bagozzi et al. 1979:88; Tung et al. 2012:998) which, in turn, affect brand loyalty.

\section{Brand loyalty}

Brand-loyal consumers are confident in their brand judgements, committed to the value and price appeal and not price sensitive, so that the same brand is purchased repeatedly (Day 1969:34). Brand loyalty can thus be reflected as being consumers' repetitive and systematic purchase of the same brand (Belaid \& Behi 2011:39), in terms of the attachment consumers have with a brand (Liu et al. 2012:924) and consumers' commitment to particular brands (Wilson et al. 2012:41).

Evidently, brand loyalty has two dimensions referred to as attitudinal- and behavioural loyalty (Kuikka \& Laukkanen 2012:522; Torres-Moraga, Vásquez-Parraga \& ZamoraGonzález 2008:303). Composite loyalty, measuring both attitudinal- and behavioural loyalty (Dick \& Basu 1994:102; Oliver 1999:34-35), is used in this study.

Intangible benefits ensure that the brand excels above other brands and result in consumer-brand relationships (such as brand romance) which can create brand loyalty (Lazarevic 2012:55-56; Patwardhan \& Balasubramanian 2011:304; Torres-Moraga et al. 2008:308). Also of pertinence to this study is that there is a direct positive effect on brand loyalty stemming from consumers' perceived enjoyment (pleasure) of using cellphone value-added services (Wang \& 
Li 2012:164, 170). As pleasure is one of the constructs used to measure brand romance, and brand attitude precedes brand loyalty (as discussed above), a clear relation between brand romance, brand attitude and brand loyalty exists within literature. Based upon the literature review presented earlier, the following alternative hypotheses were formulated:

H1: There are significant and positive relationships between brand romance, brand attitude and brand loyalty amongst cellphone users toward their cellphone brands.

$\mathrm{H} 2$ : Cellphone users perceive the underlying dimensions of both brand romance and brand loyalty as being significantly different from one another.

The hypothesis $\mathrm{H} 2$ hypothesis was then refined as follows:

$\mathbf{H}_{\mathrm{a}}$ : Cellphone users perceive the underlying dimensions of brand romance as being significantly different from one another.

$\mathbf{H 2}_{\mathbf{b}}$ : Cellphone users perceive the underlying dimensions of brand attitude as being significantly different from one another.

\section{Differences in brand preferences based on various factors}

Differences in consumer characteristics (demographic and patronage-habit differences) have been recognised widely as influencing consumer behaviour in various ways (Hawkins \& Mothersbaugh 2010:7). Concerning demographics, age plays a role in the development of consumer-brand relationships, as younger consumers show enthusiasm toward building relationships with their brands in contrast with older respondents who tend to focus on functional characteristics (Papista \& Dimitriadis 2012:48-49). Young consumers are also considered to be active users of cellphones and more likely to pursue the experiential aspect of the cellphone than other age groups (Alamro \& Rowley 2011:480; Li et al. 2012:131; Ye, Bose \& Pelton 2012:197-198). Age, gender and income (often linked to employment status and educational level) impact on the satisfaction-loyalty relationship (Homburg \& Giering 2001:48-49).

Based upon the information referred, the following alternative hypothesis has been formulated for the study:

H3: Cellphone users differ with regard to their brand romance, brand attitude and brand loyalty toward their cellphone brands, based upon their demographic differences.

This hypothesis is refined as follows:

$\mathrm{H}_{\mathrm{a}}$ : Cellphone users differ with regard to their brand romance, brand attitude and brand loyalty toward their cellphone brands, based upon generational differences.

$\mathbf{H 3}_{\mathrm{b}}$ : Cellphone users differ with regard to their brand romance, brand attitude and brand loyalty toward their cellphone brands, based upon differences in educational level.

H3: Cellphone users differ with regard to their brand romance, brand attitude and brand loyalty toward their cellphone brands, based upon gender differences.

H3 ${ }_{d}$ : Cellphone users differ with regard to their brand romance, brand attitude and brand loyalty toward their cellphone brands, based upon differences in employment status.

With respect to patronage habits, the duration of consumerbrand relationships can influence the strength of relationships
(Papista \& Dimitriadis 2012:49-50), although Homburg, Giering and Menon (2003:52) found that the length of relationship has no effect on loyalty. Based upon this, a further alternative hypothesis has been formulated for the study:

H4: Cellphone users differ with regard to their brand romance, brand attitude and brand loyalty toward their cellphone brands, based upon patronage-habit differences.

This hypothesis is then refined as follows:

$\mathrm{H}_{\mathrm{a}}$ : Cellphone users differ with regard to their brand romance, brand attitude and brand loyalty toward their cellphone brands, based upon the period over which they have been using the particular cellphone brand.

$\mathbf{H 4}_{\mathbf{b}}$ : Cellphone users differ with regard to their brand romance, brand attitude and brand loyalty toward their cellphone brands, based upon whether they are contract- or prepaid customers of cellphone networks.

\section{Problem statement, purpose and objectives}

It is evident from the literature review that the South African cellphone industry is characterised by fast growth (Sibanda 2008; SouthAfrica.info 2012) and intense competition as a variety of different cellphone handsets and smart phones have entered the market (Berger et al. 2012; Tubbs 2012). Consumers find it easy to switch between cellphone brands (Sarkar 2011:80) and marketers of cellphone brands are therefore challenged to cultivate a brand relationship between their consumers and their brand so as to ensure brand loyalty. One way of influencing attitudes and, ultimately, creating brand loyalty is to promote brand romance between the consumer and a particular cellphone brand. According to Patwardhan and Balasubramanian (2011:299), this involves associating a brand with pleasure, arousal and dominance.

The purpose of this study is therefore primarily to investigate brand romance, brand attitude and brand loyalty of consumers toward cellphone brands in South Africa, more specifically the North West Province. The purpose of this study is achieved by the formulation of the following objectives:

- Develop a demographic profile of respondents.

- Investigate the cellphone patronage habits of respondents.

- Determine the level of brand romance that cellphone users experience toward their cellphone brands.

- Determine the attitude of cellphone users toward their cellphone brands.

- Determine the level of brand loyalty that cellphone users exhibit toward cellphone brands.

- Uncover the relationship between brand romance, brand attitude and brand loyalty toward cellphone brands.

- Determine whether cellphone users differ in terms of their level of brand romance, brand loyalty and brand attitude toward their cellphone brands based upon demographic differences and cellphone patronage habits. 


\section{Research method and design}

This study is quantitative in nature and a descriptive research design (using non-probability convenience sampling) was followed since it focuses on collecting data from respondents for the purposes of calculating statistics in order to achieve clearly-defined objectives (Malhotra 2007:143). Prospective respondents in public areas were approached by fieldworkers based upon convenience, firstly to determine whether they qualified to take part in the study and, secondly, to then ask them to take part in the study. The fieldworkers were trained and supervised by the researchers concerned. The data were collected from the target population during June 2012.

The target population of the study included all those who were 18 years and older at the time of the study, resided in the North West Province of South Africa, who owned a cellphone and who were involved in the purchase of the cellphone they currently owned. A total of 400 questionnaires were fielded and the 371 usable questionnaires were included in the analysis.

The researchers employed a self-administered questionnaire containing closed-ended questions designed to achieve the objectives formulated for the study in order to collect data from the respondents. The questionnaire was structured as follows:

- A preamble provided information explaining the purposes of the questionnaire as well as the rights of the respondents. Screening questions were also included in this section so as to ensure that only eligible respondents completed the questionnaire.

- Section A then included questions designed to develop a demographic profile of respondents.

- Section B examined the cellphone patronage habits of respondents.

- Section C contained a five-point Likert-type scale, where 1 was 'strongly disagree' and 5 was 'strongly agree', containing the statements that measured the constructs of the study. To measure brand attitude, a scale was adapted from Wu and Wang (2011) who developed the scale based upon the work of Delgado-Ballester (2004), Chaudhuri and Holbrook (2002) and Dodds, Monroe and Grewal (1991). Finally, to measure brand romance, a scale was adopted from Patwardhan and Balasubramanian (2011) and to measure brand loyalty, a scale was adopted from the work of Keller (2001).

\section{Data analysis}

The Statistical Package for Social Sciences (SPSS), Version 20, was used to analyse the data. Before analysis commenced, the data were captured and subsequently cleaned by rectifying all transcription errors by returning to the completed questionnaires to check the correct response.

The frequencies for all demographic and cellphone patronage-habit variables were calculated (see Tables 1 and 2). The descriptive statistics, means and standard deviations for all statements measuring the constructs under study were also calculated (see Table 3). Reliability statistics for the constructs and their underlying dimensions as reported in Table 4 were also calculated. Construct validity was also assessed and reported on. Subsequently, overall mean scores for these constructs and the underlying dimensions were calculated and are presented in Table 4.

For the purposes of hypothesis testing, the response categories for two demographic variables and one cellphone patronage-habit variable were collapsed in order to draw comparisons between the means of possible groups. The response categories of the 'highest level of education' variable were collapsed into two categories, namely those who had an education level of matric or less and those who had an education level higher than matric. The response categories of the 'employment status' variable were collapsed into two categories, namely those who were full-time employed and those who were part-time employed or unemployed. Finally, the response categories of the 'time with current cellphone brand' variable were collapsed into two categories, namely those who had been using a particular cellphone brand for three years or less and those who had been using a particular cellphone brand for more than three years.

In order to test the hypotheses formulated for the study, a number of parametric tests were conducted. A subsequent section addresses the decision to use parametric tests. The researchers relied on a $95 \%$ confidence level and a subsequent significance level of $5 \%$ ( $p$-value $\leq 0.05$ ) to interpret the results of the hypothesis testing. The following tests were conducted:

- To determine whether significant and positive relationships exist between constructs, Pearson product moment correlations were performed to test H1. A correlation coefficient $(r)$ of $>0.5$ indicates a strong correlation between the two variables, an $r$ of $0.3-0.5$ indicates a moderate correlation and an $r$ of $0.1-0.3$ a weak correlation (Eiselen, Uys \& Potgieter 2007:87). The $p$-value and correlation coefficient are reported for each correlation (Pallant 2010:135).

- To determine significant differences between the means of pairs of variables, paired sample $t$-tests were conducted to test H2 (Pallant 2010:244) and means and $p$-values are reported.

- To determine significant differences between the means of groups for a combination of dependent variables, multivariate analysis of variance (MANOVA) tests were performed to test $\mathrm{H} 3$ and $\mathrm{H} 4$. In each instance, the F-value, $p$-value, Wilks' Lambda and the partial eta squared are reported where appropriate. A $p$-value of 0.05 initially signals a significant difference between groups, whilst a Bonferonni adjustment to the $p$-value signals significant differences between groups with respect to each dependent variable (Pallant 2010:293-296).

\section{Results}

This section presents the findings in the order as discussed in the section on data analysis. 


\section{Respondent profile}

The demographic profile of respondents is presented in Table 1.

It is evident from Table 1 that the majority of respondents belong to Generation $Y$ and are 26 years and younger (57.5\%). There is a fairly equal balance between the genders, with slightly more women $(52.6 \%)$ than men $(47.4 \%)$. Over $90 \%$ of respondents completed school or have a higher qualification and the majority (56.6\%) are employed fulltime.

\section{Cellphone patronage habits of respondents}

Table 2 provides an exposition of the cellphone patronage habits of respondents.

As shown in Table 2, nearly three-quarters of the respondents $(73.3 \%)$ are contract customers, whilst the remaining quarter $(26.7 \%)$ are prepaid customers of cellphone network companies. Half of the respondents $(50.0 \%)$ have Blackberry cellphones and just over a quarter (26.8\%) have Nokia cellphones. The majority $(39.1 \%)$ of respondents have been using their current brand of cellphone for one year or longer, but less than three years.

\section{Brand romance, brand attitude and brand loyalty}

Table 3 provides an exposition of the results obtained for each statement, underlying dimensions and constructs measured in the study. The table presents the mean and standard deviation for each statement and the mean score calculated for each underlying dimension and construct.

Based upon Table 3, the following findings can be observed:

- The statement 'I am really happy that this brand is available' realised the highest mean of all statements, measuring brand romance with a mean of 3.90. The statement 'Sometimes I feel I cannot control my thoughts as they are obsessively focused on this brand' obtained the lowest mean of 1.66. The underlying dimensions of brand romance realised a mean of 3.67 for pleasure, a mean of 3.44 for arousal and a mean of 1.81 for dominance. The overall mean for brand romance is 2.98 .

- The statement 'I feel confidence in this brand' obtained the highest mean of all brand attitude statements, with a mean of 3.57. The statement 'The company which owns this brand will compensate me for a problem I experience with the brand' obtained the lowest mean, 2.93. The underlying dimensions of brand attitude realised a mean of 3.28 for trust and a mean of 3.25 for affection. The overall mean for brand attitude is 3.27 .

- The statement "This is the one brand I would prefer to buy or use' obtained the highest mean of all brand loyalty statements measured, with a mean of 3.18. The statement 'I buy as much of this brand as I can' obtained the lowest mean of 2.26. The overall mean for brand loyalty is 2.74 .
TABLE 1: Demographic profile of respondents.

\begin{tabular}{lcc}
\hline Demographic profile & Frequency & \% \\
\hline Generation (in 2012) & & \\
Generation Y (26 years and younger) & 208 & 57.5 \\
Generation X (27-47 years) & 77 & 21.3 \\
Baby Boomers (48-66 years) & 77 & 21.3 \\
Highest level of education & & \\
Primary school completed & 3 & 0.8 \\
Some high school & 28 & 7.5 \\
Completed high school & 129 & 34.8 \\
Tech diploma/degree- diploma or degree obtained & 81 & 21.8 \\
from a former Technikon & & \\
University degree or postgraduate degree - degree & 130 & 35.0 \\
or post-graduate degree obtained from a University & & \\
Gender & 176 & 47.4 \\
Men & 195 & 52.6 \\
Women & & \\
Employment status & 210 & 56.6 \\
Full-time employed & 19 & 5.1 \\
Part-time employed & 30 & 8.1 \\
Self-employed & 83 & 22.4 \\
Student & 9 & 2.4 \\
Housewife or househusband & 14 & 3.8 \\
Retired & 6 & 1.6 \\
Unemployed & & \\
\hline & & \\
\hline
\end{tabular}

TABLE 2: Cellphone patronage habits of respondents.

\begin{tabular}{lcc}
\hline Cellphone patronage & Frequency & $\mathbf{\%}$ \\
\hline Type of cellphone network customer & 272 & 73.3 \\
Contract customer & 99 & 26.7 \\
Prepaid customer & & \\
Cellphone brand currently used & 185 & 50.0 \\
Blackberry & 99 & 26.8 \\
Nokia & 42 & 11.4 \\
Samsung & 25 & 6.8 \\
Apple & 9 & 2.4 \\
HTC & 5 & 1.4 \\
Sony Ericsson & 2 & 0.5 \\
Motorola & 2 & 0.5 \\
LG & 1 & 0.3 \\
Vodafone & & \\
Time with current cellphone brand & 49 & 13.2 \\
Less than 6 months & 72 & 19.4 \\
6 months or longer, but less than 1 year & 145 & 39.1 \\
1 year or longer, but less than 3 years & 53 & 14.3 \\
3 years or longer, but less than 5 years & 32 & 8.6 \\
5 years or longer, but less than 10 years & 20 & 5.4 \\
Longer than 10 years & &
\end{tabular}

\section{Determining the appropriate statistical techniques to test hypotheses}

Before any statistical technique can be used to test a hypothesis, it is necessary to assess whether the assumptions for using these tests are being met. In order to use a Pearson product-moment correlation to determine the strength and direction of a relationship between two variables, the researchers had to (1) identify possible outliers, (2) assess the normality of distribution of data, (3) determine whether the relationship between the two variables is positive or negative and (4) determine whether the relationship is linear in nature (Pallant 2010:129-135). Once these assumptions were met, the researchers could proceed with conducting Pearson productmoment correlations. In order to use a paired-sample $t$-test it 
TABLE 3: Brand romance, brand attitude and brand loyalty of respondents toward their cellphone brands.

\begin{tabular}{|c|c|c|c|c|c|}
\hline Constructs & Underlying dimensions & Statements & Standard deviation & Mean & Total mean \\
\hline \multirow[t]{13}{*}{ Brand romance } & & & & & 2.98 \\
\hline & Pleasure & I love this brand & 0.970 & 3.78 & 3.67 \\
\hline & & Using this brand gives me great pleasure & 0.994 & 3.79 & \\
\hline & & I am really happy that this brand is available & 1.008 & 3.90 & \\
\hline & & This brand rarely disappoints me & 1.251 & 3.13 & \\
\hline & Arousal & I am attracted to this brand & 1.028 & 3.49 & 3.44 \\
\hline & & I desire this brand & 1.116 & 3.25 & \\
\hline & & I want this brand & 1.104 & 3.49 & \\
\hline & & I look forward to using this brand & 1.117 & 3.54 & \\
\hline & Dominance & My daydreams often include this brand & 1.152 & 1.96 & 1.81 \\
\hline & & This brand often dominates my thoughts & 1.096 & 1.86 & \\
\hline & & $\begin{array}{l}\text { Sometimes I feel I cannot control my thoughts as they are focused } \\
\text { obsessively on this brand }\end{array}$ & 1.015 & 1.66 & \\
\hline & & This brand always seems to be on my mind & 1.064 & 1.76 & \\
\hline \multirow[t]{16}{*}{ Brand attitude } & & & & & 3.27 \\
\hline & & I feel confidence in this brand & 1.054 & 3.57 & \\
\hline & & This is a brand that will not disappoint me & 1.071 & 3.33 & \\
\hline & & This brand guarantees satisfaction & 1.059 & 3.36 & \\
\hline & & $\begin{array}{l}\text { This company which owns this brand will be honest and sincere in } \\
\text { addressing my concerns }\end{array}$ & 1.018 & 3.16 & \\
\hline & & $\begin{array}{l}\text { I could rely on the company which owns this brand to solve a problem } \\
\text { I experience with the brand }\end{array}$ & 1.032 & 3.25 & \\
\hline & & The company which owns this brand will make any effort to satisfy me & 1.017 & 3.13 & \\
\hline & & $\begin{array}{l}\text { The company which owns this brand will compensate me for a problem } \\
\text { l experience with the brand }\end{array}$ & 1.100 & 2.93 & \\
\hline & Brand affection & I feel good if I purchase this brand & 1.145 & 3.28 & 3.25 \\
\hline & & This brand makes me happy & 1.193 & 3.31 & \\
\hline & & This brand gives me pleasure & 1.224 & 3.15 & \\
\hline & Brand loyalty & I consider myself loyal to this brand & 1.263 & 2.99 & 2.74 \\
\hline & & I buy this brand whenever I can & 1.309 & 2.80 & \\
\hline & & I buy as much of this brand as I can & 1.245 & 2.26 & \\
\hline & & $\begin{array}{l}\text { If this brand was unavailable, it would be difficult if I had to use } \\
\text { another brand }\end{array}$ & 1.307 & 2.66 & \\
\hline & & I would go out of my way to buy this brand & 1.241 & 2.67 & \\
\hline
\end{tabular}

is important to ensure that the independent variable is either nominal or ordinal in scale and that the dependent variable is interval or ratio scaled (Pallant 2010:114). In order to perform a MANOVA, the researchers had to ensure an adequate sample size, identify possible outliers, assess the normality of distribution of data, ensure the relationships between pairs of dependent are linear in nature and ensure that the variables correlate moderately (Pallant 2010:285-290).

\section{Reliability}

The scales measuring brand romance, brand attitude and brand loyalty have either been adopted or adapted from the work of others. Since the study was conducted within a South African context, it is deemed important to assess the internal-consistency reliability of these scales by calculating the Cronbach's alpha coefficient for each. According to Pallant (2010:6), the Cronbach's alpha coefficient value for a particular scale varies between 0 and 1 . The closer the value is to 1 , the more reliable the scale is deemed to be, whilst a value closer to 0 is indicative of a less-reliable scale. A cut-off point of 0.7 is used to decide whether a scale can be considered reliable or not (Pallant 2010:6). Table 4 presents the Cronbach's alpha coefficient values for the three constructs, as well as their underlying dimensions, where applicable.
TABLE 4: Cronbach's alpha values for the measurement sets.

\begin{tabular}{ll}
\hline Constructs and underlying dimensions & Cronbach's alpha value \\
\hline Brand romance (12 statements) & $\mathbf{0 . 8 8 7}$ \\
Pleasure (4 statements) & 0.785 \\
Arousal (4 statements) & 0.903 \\
Dominance (4 statements) & 0.912 \\
Brand attitude (11 statements) & $\mathbf{0 . 9 3 7}$ \\
Trust (8 statements) & 0.917 \\
Affection (3 statements) & 0.918 \\
Brand loyalty (7 statements) & $\mathbf{0 . 9 1 4}$
\end{tabular}

It is evident from Table 4 that the Cronbach's alpha coefficient values for the constructs and underlying dimensions are all above 0.7 , indicating that the scales are reliable. Such a result allows a researcher to calculate overall mean scores for the underlying dimensions and constructs, allowing for the comparison of the means of different groups and variables when hypotheses are tested.

\section{Construct validity}

Patwardhan and Balasubramanian (2011) illustrate both discriminant- and convergent validity for the scale measuring the brand romance construct. Furthermore, for each of the three dimensions of the brand romance, construct validity was assessed with the aid of a confirmatory factor analysis using the Maximum Likelihood Model for extraction and 
Varimax for orthogonal rotation (Matsunaga 2010:107; Pallant 2010:185).

For the pleasure dimension, the construct validity was confirmed since only one factor could be extracted, explaining $66.58 \%$ of the variance. The same goes for the arousal- and dominance dimensions where only one factor could be extracted, explaining $77.48 \%$ and $79.49 \%$ of the variance respectively.

Wu and Wang (2011) illustrate discriminant- and convergent validity for the scale measuring the construct 'brand attitude' taken from the work of Chaudhuri and Holbrook (2002), Delgado-Ballester (2004) and Dodds et al. (1991). Construct validity was confirmed for the affection dimension of brand attitude since only one factor could be extracted, explaining $85.97 \%$ of the variance. For the trust dimension of brand attitude, two factors explaining $76.55 \%$ of the variance could be extracted but a second-order factor analysis was considered redundant and only one second-order factor could be revealed.

The scale measuring brand loyalty was taken from the work of Keller (2001). Construct validity was confirmed for this construct since only one factor could be extracted, explaining $66.17 \%$ of the variance.

\section{Hypothesis testing}

Based on the four alternative hypotheses formulated for this study, the following findings are reported.

\section{Hypothesis 1}

With regard to $\mathrm{H} 1$, proposing that there are significant and positive relationships between brand romance, brand attitude and brand loyalty amongst cellphone users toward their cellphone brands, the following findings were made based upon the Pearson product-moment correlations that were conducted:

- There is a significant and strong positive relationship ( $p$-value $<0.0005 ; r=0.751$ ) between brand romance and brand attitude.

- There is a significant and strong positive relationship ( $p$-value $<0.0005 ; r=0.765$ ) between brand romance and brand loyalty.

- There is a significant and strong positive relationship ( $p$-value $<0.0005 ; r=0.768$ ) between brand attitude and brand loyalty.

$\mathrm{H} 1$, proposing that there are significant and positive relationships between brand romance, brand attitude and brand loyalty amongst cellphone users toward their cellphone brands, can therefore be accepted.

\section{Hypothesis 2}

With regard to $\mathrm{H} 2$, proposing that cellphone users perceive the underlying dimensions of both brand romance and brand attitude as being significantly different from one another, the following findings were made using a paired sample $t$-test:
- Cellphone users perceive the underlying dimensions of brand romance as being significantly different from one another. They derive significantly more pleasure (mean = 3.67) from their current cellphone brands than the extent to which they are aroused by their cellphone brands (mean $=3.44 ; p$-value < 0.0005). They also derive significantly more pleasure (mean $=3.67$ ) from their current cellphone brands than the extent to which their current cellphone brands are dominant (mean $=1.81 ; p$-value $<0.0005)$ in their lives. Finally, they are significantly more aroused (mean $=3.44$ ) by their cellphone brands than the extent to which their current cellphone brands are dominant in their lives $($ mean $=1.81 ; p$-value $<0.0005)\left(\mathrm{H}_{2}\right.$ a).

- Cellphone users donot perceive the underlying dimensions of brand attitude as being significantly different from one another, as a significant difference between trust (mean = $3.28)$ and affection $($ mean $=3.25 ; p$-value $=0.320$ ) could not be uncovered $\left(\mathrm{H}_{\mathrm{b}}\right)$.

$\mathrm{H} 2$, proposing that cellphone users perceive the underlying dimensions of brand romance as being significantly different from one another, can therefore be accepted.

$\mathrm{H} 2_{\mathrm{b}}$, proposing that cellphone users perceive the underlying dimensions of brand attitude as being significantly different from one another, can therefore not be accepted.

\section{Hypothesis 3}

With regard to $\mathrm{H} 3$, proposing that cellphone users differ with regard to their brand romance, brand attitude and brand loyalty toward their cellphone brands based upon their demographic differences, the following findings were made using MANOVAs:

- Cellphone users do not differ with regard to their brand romance, brand attitude and brand loyalty toward their cellphone brands based upon generational differences $(F$ $=1.121 ; p$-value $=0.348 ;$ Wilks' Lambda $=0.981)(\mathrm{H} 3$ a $)$.

- Cellphone users do not differ with regard to their brand romance, brand attitude and brand loyalty toward their cellphone brands based upon different levels of education $\left(F=1.789 ; p\right.$-value $=0.149 ;$ Wilks ${ }^{\prime}$ Lambda $\left.=0.985\right)\left(\mathrm{H}_{\mathrm{b}}\right)$.

- Upon initial investigation, it seems that cellphone users differ with regard to their brand romance, brand attitude and brand loyalty toward their cellphone brands based upon gender $(F=3.473$; $p$-value $=0.016$; Wilks' Lambda $=$ 0.972 ; partial eta squared $=0.028$ ). When considering the results of each dependent variable in isolation based upon the $p$-value of 0.017 (a Bonferroni adjustment was made to the $p$-value to compensate for the three simultaneous comparisons made by the MANOVA), no statisticallysignificant differences could be uncovered between men and women for brand romance ( $p$-value $=0.018)$, brand attitude $(p$-value $=0.499)$ and brand loyalty $(p$-value $=$ $0.035)\left(\mathrm{H} 3_{c}\right)$.

- Cellphone users do not differ with regard to their brand romance, brand attitude and brand loyalty toward their cellphone brands based upon differences in employment status $(F=0.623 ; p$-value $=0.600 ;$ Wilks' Lambda $=0.995)$ $\left(\mathrm{H} 3_{\mathrm{d}}\right)$. 
$\mathrm{H} 3$, proposing that cellphone users differ with regard to their brand romance, brand attitude and brand loyalty toward their cellphone brands based upon their demographic differences, can therefore not be accepted.

\section{Hypothesis 4}

With regard to $\mathrm{H} 4$, proposing that cellphone users differ with regard to their brand romance, brand attitude and brand loyalty toward their cellphone brands based upon patronage habit differences, the following findings were made using MANOVAs:

- Upon initial investigation, it seems that cellphone users differ with regard to their brand romance, brand attitude and brand loyalty toward their cellphone brands, based upon the period they have been using the particular cellphone brand $\left(F=4.369 ; p\right.$-value $=0.005 ; W^{2}$ Wilks $^{\prime}$ Lambda $=0.964 ;$ partial eta squared $=0.036)$. When considering the results of each dependent variable in isolation, based upon a $p$-value of 0.017 (a Bonferroni adjustment was made to the $p$-value to compensate for the three simultaneous comparisons made by the MANOVA), no statistically-significant differences could be uncovered based upon the period for which they have been using the particular cellphone brand for brand romance ( $p$-value $=$ $0.971)$, brand attitude ( $p$-value $=0.702)$ and brand loyalty $(p$-value $=0.029)\left(\mathrm{H}_{\mathrm{a}}\right)$.

- Cellphone users do not differ with regard to their brand romance, brand attitude and brand loyalty towards their cellphone brands based upon whether they are contract or prepaid customers of cellphone networks $(F=1.617$; $p$-value $=0.185 ;$ Wilks' Lambda $=0.987)\left(\mathrm{H}_{\mathrm{b}}\right)$.

$\mathrm{H} 4$, proposing that cellphone users differ with regard to their brand romance, brand attitude and brand loyalty toward their cellphone brands based upon patronage habit differences, can therefore not be accepted.

\section{Ethical considerations}

This study involved humans in that it focused on the collection of data with regard to the opinions and perceptions of consumers toward a particular product, a cellphone. Cellphones are used regularly in both private- and in public space and are widely-accepted communication devices. Questioning respondents regarding cellphones did not result in psychological or physical, risk, strain or exposure. The execution of the study, furthermore, complies with the institutional guidelines governing the execution of research projects undertaken by its staff.

\section{Potential benefits and hazards}

Respondents were asked to complete a questionnaire and to return it to the fieldworker upon completion. The physical risk was minimal since all that was expected of respondents was to mark suitable responses with pen or pencil on the questionnaire itself. Furthermore, the questionnaire took less than ten minutes to complete, limiting unnecessary time delays as well as physical- and psychological strain on the respondents. The content of the survey did, however, include any questions that could be considered to be sensitive in nature.

\section{Recruitment procedures}

Prospective respondents were approached by fieldworkers with a structured self-administered questionnaire on the basis of convenience in public areas. Participation was completely voluntary and the respondents could withdraw at any stage. Respondents were furthermore not asked to provide any private credentials or identifiable data, ensuring that the data were completely anonymous and could not be linked to any particular respondent.

\section{Informed consent}

The questionnaire commenced with a preamble explaining the purpose of the study as well as the rights and obligations of the respondents. Screening questions were used to ensure that prospective respondents fit the criteria for participation in the study. Once the preamble was read, the respondent could either agree or refuse to take part in the study. Once the respondent agreed to take part, the questionnaire was handed to them for completion.

\section{Data protection}

To ensure data protection, the completed questionnaires were stored in a locked cabinet and the collected data were stored on one author's password-protected computer.

\section{Discussion and recommendations}

It is evident from the findings that nearly three-quarters of the respondents are contract customers, which implies that these consumers use a particular cellphone brand for the duration of the contract period. It is therefore critical for marketers to convince contract consumers to select their particular brand when a contract is entered into with a cellphone network service provider, since this will be the brand of cellphone a particular customer will use for a 24-month period, in most instances. During the contract period, marketers should focus on reinforcing the attitudes of those who have chosen their cellphone brand and changing the attitudes of those who have not yet chosen their brands. Prepaid consumers are also a viable opportunity for marketers of cellphone brands, since they have more flexibility in changing from one handset brand to another.

It is also evident that the majority of respondents use a brand of cellphone for between one and three years, which is indicative of a fair amount of brand switching taking place in the handset market. It is thus imperative for marketers of cellphone brands to retain customers, once they have chosen their particular brand, beyond the current contract period. Strategies to prevent switching include communicating the risk involved with switching, the difficulty of evaluating alternatives (for example, new innovative features of other cellphone brands), the hassles of setting up a new relationship 
as well as increasing the strength of consumers' psychological bonds (for example, increasing brand romance) with the brand (Burnham, Frels \& Mahajan 2003:120).

The results also indicate that brand romance toward current cellphone brands is positive, although plenty of room for improvement exists. As proposed by Patwardhan and Balasubramanian (2011:304), marketers of cellphone brands should focus on providing brands which offer consumers novel activities in order to increase and maintain brand romance. These novel activities should not only be focused on technological developments of cellphone handsets (the product), but could also include the other aspects of marketing, such as new distribution channels, adapting prices, repositioning the brand and communicating as a partner with consumers instead of a business partner out for profit gain.

Brand attitude toward current cellphone brands is also positive. To enhance and maintain brand attitude in terms of trust and affection, marketers of cellphone brands should establish trust through open lines of communication, provide guarantees on their product brand, establish the brand as socially acceptable by considering consumers' interests and welfare and provide benefits that consumers regard as being important.

Brand loyalty realised a mean that indicated fairly low brand loyalty. It is therefore imperative for marketers of cellphone brands to improve brand loyalty toward their cellphone brand as the apparent lack of brand loyalty is echoed in the patronage habits of respondents. Brand loyalty can be improved by matching the cellphone brand closely with the aspirations and wants of the selected target market. Brand romance, trust in the brand (as part of consumers' brand attitude), positive experiences with the brand and intangible benefits offered by the brand (increasing consumers' confidence that their brand will satisfy their needs), may contribute even more toward moving consumers who are new to the brand or not yet loyal, to becoming brand-loyal consumers.

Furthermore, the results indicate significant and positive relationships between brand romance, brand attitude and brand loyalty toward cellphone brands. Brand romance can thus be considered a viable way of improving consumer attitude toward a cellphone brand, ultimately leading to brand loyalty. Generating brand romance between a cellphone brand and consumers could thus eventually pay off in brand loyalty. This can be done by associating the brand with pleasure and assuring that the brand is distributed effectively.

With regard to brand romance, the respondents indicate that they derive pleasure from their cellphone brands. Their current brand of cellphone arouses them to a limited extent and they do not consider the specific brand to be particularly dominant in their lives. An opportunity thus exists for marketers to either capitalise on the pleasure dimension of brand romance, since it is already a powerful dimension with respect to cellphone brands, or to improve arousal and dominance toward their particular cellphone brand amongst customers, since these are weak dimensions of brand romance. Marketers of cellphone brands should therefore focus on providing satisfactory products and services in order to elicit pleasure (Mugge et al. 2010:279). Furthermore, marketers of cellphone brands can remind consumers continuously by means of marketing communications of the pleasure associated with using their cellphone brand for value-added functions such as social networking, internet access (banking, shopping and browsing) and applications, in an effort to intensify their pleasure and arouse the consumers. Frequent interaction between the marketers of cellphone brands and consumers may result in the brand becoming more dominant in consumers' lives (Patwardhan \& Balasubramanian 2011:304). Differentiation might also cause higher brand romance through increasing arousal and dominance, as differentiation establishes stronger bonds of identity (Burnham et al. 2003:119) and thus attachment. Differentiation is possible through being at the cutting edge of technological developments or by being a cost leader in the industry.

Respondents do not differ with regard to their brand romance, brand attitude and brand loyalty toward their cellphone brands based upon demographic or patronage habit differences. From these results, it does not seem that it would be viable for marketers to differentiate their target market according to demographics or patronage habits when trying to increase their consumers' brand romance, brand attitude and brand loyalty.

\section{Limitations and future research}

A number of limitations of this study are evident. The target population of the study is limited to cellphone users in the North West Province of South Africa and a non-probability convenience sample was used, limiting the ability of the researchers to generalise findings to the study population. As was the case in the study conducted by Patwardhan and Balasubramanian (2011:305) on brand romance, this study neither uncovers the reasons for which consumers engage in a 'romance' with a brand, nor how it can be instilled in consumers.

Several suggestions for future research can also be made. Since brand romance is considered to be specific to a particular product (Patwardhan \& Balasubramanian 2011:299), opportunities exist to measure it for different products in different contexts. Since previous studies found differences based upon culture relating to consumer-brand relationships with cellphone brands (Hakala, Svensson \& Vincze 2012:445; Liu et al. 2012:933), this can be explored further. A longitudinal study could also be undertaken in order to measure brand romance, brand attitude and brand loyalty toward cellphone brands over time.

As brand romance in brand relationships is related positively to brand attitude and brand loyalty, this study identified brand romance as being a viable option for cellphone marketers to improve brand attitude and brand loyalty amongst their consumers. 


\section{Acknowledgments Competing interests}

The authors declare that they have no financial or personal relationship(s) which may have inappropriately influenced them in writing this article.

\section{Authors' contributions}

P.G.M. (North-West University) was the project leader. L.K. (North-West University) and S.W.K. (North-West University) wrote the literature review. D.J.P. (North-West University) compiled the questionnaire, coordinated the fieldwork and wrote up the research methodology and results. All members of the team contributed to the conclusion and managerial implications.

\section{References}

Alamro, A. \& Rowley, J., 2011, 'Antecedents of brand preference for mobile telecommunications services', Journal of Product \& Brand Management, 20(6), 475-486. http://dx.doi.org/10.1108/10610421111166621

Aurier, P. \& De Lanauze, G.S., 2011, 'Impacts of in-store manufacturer brand expression on perceived value, relationship quality and attitudinal loyalty', Internationa Journal of Retail \& Distribution Management, 39(11), 810-835. http://dx.doi. org/10.1108/09590551111177945

Bagozzi, R.P., Tybout, A.M., Craig, C.S. \& Sternthal, B., 1979, 'The construct validity of the tripartite classification of attitudes', Journal of Marketing Research, 16(1) 88-95. http://dx.doi.org/10.2307/3150879

Belaid, S. \& Behi, A.T., 2011, 'The role of attachment in building consumerbrand relationships: an empirical investigation in the utilitarian consumption context', Journal of Product \& Brand Management, 20(1), 37-47. http://dx.doi. org/10.1108/10610421111108003

Berger, G., Sinha, A. \& Pawelczyk, K., 2012, 'South African mobile generation: study on South African young people on mobiles', viewed 24 October, from http://www. unicef.org/southafrica/SAF_resources_mobilegeneration.pdf

Burnham, T.A., Frels, J.K. \& Mahajan, V., 2003, 'Consumer switching costs: a typology, antecedents and consequences', Journal of the Academy of Marketing Science, antecedents and consequences', Journal of the Academy of M
31(2), 109-126. http://dx.doi.org/10.1177/0092070302250897

Chaudhuri, A. \& Holbrook, M.B., 2002, 'Product-class effects on brand commitment and brand outcomes: the role of brand trust and brand affect', Journal of Brand Management, 10(1), 33-58. http://dx.doi.org/10.1057/palgrave.bm.2540100

Day, G.S., 1969, 'A two-dimensional concept of brand loyalty', Journal of Advertising Research, 9(3), 29-35.

Delgado-Ballester, E., 2004, 'Applicability of a brand trust scale across product categories: a multigroup invariance analysis', European Journal of Marketing, 38(5/6), 573-592. http://dx.doi.org/10.1108/03090560410529222

Dick, A.S. \& Basu, K., 1994, 'Customer loyalty: toward an integrated conceptual framework', Journal of the Academy of Marketing Science, 22(2), 99-113. http:// dx.doi.org/10.1177/0092070394222001

Dodds, W.B., Monroe, K.B. \& Grewal, D., 1991, 'Effects of price, brand, and store information on buyers' product evaluations', Journal of Marketing Research, 28(3), 307-319. http://dx.doi.org/10.2307/3172866

Eiselen, R., Uys, T. \& Potgieter, T., 2007, Analysing survey data using SPSS 13, 3rd edn., Statkon, University of Johannesburg.

Fishbein, M., 1963, 'An investigation of the relationships between beliefs about an object and the attitude toward that object', Human Relations, 16, 233-239. http://dx.doi.org/10.1177/001872676301600302

Franzak, F. \& Pitta, D., 2011, 'Moving from service dominant to solution dominant brand innovation', Journal of Product \& Brand Management, 20(5), 394-401. http://dx.doi.org/10.1108/10610421111157919

Fripp, C., 2012, 'Africa's top-selling mobile handsets', IT News Africa, viewed 17 May 2013, from http://www.itnewsafrica.com/2012/08/africas-top-selling-mobilehandsets/

Hakala, U., Svensson, J. \& Vincze, Z., 2012, 'Consumer-based brand equity and top-of-mind awareness: a cross-country analysis', Journal of Product \& Brand Management, 21(6), 439-451. http://dx.doi.org/10.1108/10610421211264928

Hawkins, D.I. \& Mothersbaugh, D.L., 2010, Consumer behavior: building marketing strategy, McGraw-Hill, New York.

Hess, J., Story, J. \& Danes, J., 2011, 'A three-stage model of consumer relationship investment', Journal of Product \& Brand Management, 20(1), 14-26. http:// dx.doi.org/10.1108/10610421111107987

Homburg, C. \& Giering, A., 2001, 'Personal characteristics as moderators of the relationship between customer satisfaction and loyalty - an empirical analysis', Psychology \& Marketing, 18(1), 43-66. http://dx.doi.org/10.1002/1520 6793(200101)18:1<43::AID-MAR3>3.0.CO;2-1

Homburg, C., Giering, A. \& Menon, A., 2003, 'Relationship characteristics as moderators of the satisfaction-loyalty link: finding in a business-to-business
context', Journal of Business-to-Business Marketing, 10(3), 35-62. http://dx.doi. context', Journal of Business-to-
org/10.1300/J033v10n03_02
Hoyer, W.D., MacInnis, D.J. \& Pieters, R., 2013, Consumer behavior, 6th international edn., South-Western Cengage Learning, Mason, Ohio.

Hwang, J. \& Kandampully, J., 2012, 'The role of emotional aspects in younger consumer-brand relationships', Journal of Product \& Brand Management, 21(2) 98-108. http://dx.doi.org/10.1108/10610421211215517

Ismail, A.R. \& Spinelli, G., 2012, 'Effects of brand love, personality and image on word of mouth: the case of fashion brands among young consumers', Journa of Fashion Marketing and Management, 16(4), 386-398. http://dx.doi. org/10.1108/13612021211265791

Keller, K.L., 2001, 'Building customer-based brand equity: a blueprint for creating strong brands', Marketing Sciences Institute, 1(107), 1-31.

Kuikka, A. \& Laukkanen, T., 2012, 'Brand loyalty and the role of hedonic value', Journal of Product \& Brand Management, 21(7), 529-537. http://dx.doi. org/10.1108/10610421211276277

Lazarevic, V., 2012, 'Encouraging brand loyalty in fickle generation Y consumers', Young Consumers: Insight and Ideas for Responsible Marketers, 13(1), 45-61. http://dx.doi.org/10.1108/17473611211203939

Li, M., Dong, Z.Y. \& Chen, X., 2012, 'Factors influencing consumption experience of mobile commerce: a study from experiential view', Internet Research, 22(2), 120141. http://dx.doi.org/10.1108/10662241211214539

Liu, F., Li, J., Mizerski, D. \& Soh, H., 2012, 'Self-congruity, brand attitude, and brand loyalty: a study on luxury brands', European Journal of Marketing, 46(7/8), 922937. http://dx.doi.org/10.1108/03090561211230098

Long-Tolbert, S.J. \& Gammoh, B.S., 2012, 'In good and bad times: the interpersonal nature of brand love in service relationships', Journal of Services Marketing, 26(6), 391-402. http://dx.doi.org/10.1108/08876041211257882

Malhotra, N.K., 2007, Marketing research: an applied orientation, 5th edn., Pearson Prentice Hall, Upper Saddle River, N.J.

Matsunaga, M., 2010, 'How to factor-analyze your data right: do's, don'ts, and howto's', International Journal of Psychological Research, 3(1), 97-110.

Mugge, R., Schifferstein, H.N.J. \& Schoormans, J.P.L., 2010, 'Product attachment and satisfaction: understanding consumers' post-purchase behavior', Journal of Consumer Marketing, 27(3), 271-282. http://dx.doi. behavior', Journal of Consumer
org/10.1108/07363761011038347

Oliver, R.L., 1999, 'Whence consumer loyalty?', Journal of Marketing. Fundamental Issues and Directions for Marketing, 63, 33-44.

Pallant, J., 2010, SPSS Survival manual, 3rd edn., McGraw-Hill, New York.

Papista, E. \& Dimitriadis, S., 2012, 'Exploring consumer-brand relationship quality and identification: qualitative evidence from cosmetics brands', Qualitative Market Research: An International Journal, 15(1), 33-56. http://dx.doi. Market Research: An Internation
org/10.1108/13522751211191982

Patwardhan, H. \& Balasubramanian, S.K., 2011, 'Brand romance: a complementary approach to explain emotional attachment toward brands', Journal of Product \& Brand Management, 20(4), 297-308. http://dx.doi. Journal of Product \& Brand Man
org/10.1108/10610421111148315

Petruzzellis, L., 2010, 'Mobile phone choice: technology versus marketing. The brand effect in the Italian market', European Journal of Marketing, 44(5), 610-634. http://dx.doi.org/10.1108/03090561011032298

Sarkar, A., 2011, 'Romancing with a brand: a conceptual analysis of romantic consumer-brand relationship', Management \& Marketing, 6(1), 79-94.

Sibanda, M., 2008, 'South Africa's mobile industry rated fourth fastest growing', viewed 24 October 2012, from http://www.itnewsafrica.com/2008/11/southafricas-mobile-industry-rated-fourth-fastest-growing/

Solomon, M.R., 2013, Consumer behavior: buying, having, and being, 10th global edn., Pearson Education Limited, Harlow, U.K.

SouthAfrica.info, 2012, 'South Africa's telecommunications', viewed 24 October 2012 from http://www.southafrica.info/business/economy/infrastructure/telecoms.htm

South African Advertising Research Foundation, 2012, 'Cell phone trends', viewed 24 October 2012, from http://www.saarf.co.za/amps/cellphone.asp

Torres-Moraga, E., Vásquez-Parraga, A.Z. \& Zamora-González, J., 2008, 'Customer satisfaction and loyalty: start with the product, culminate with the brand', Journal of Consumer Marketing, 25(5), 302-313. http://dx.doi. the brand', Journal of Consumer
org/10.1108/07363760810890534

Tubbs, B., 2012, 'SA's cellphone market defined', viewed 24 October 2012, from http:// www.itweb.co.za/index.php?option=com_content\&view=article\&id=57235

Tung, S.J., Shih, C.C., Wei, S. \& Chen, Y.H., 2012, 'Attitudinal inconsistency toward organic food in relation to purchasing intention and behaviour: an illustration of Taiwan consumers', British Food Journal, 114(7), 997-1015. http://dx.doi. org/10.1108/00070701211241581

Wang, W.T. \& Li, H.M., 2012, 'Factors influencing mobile services adoption: a brand-equity perspective', Internet Research, 22(2), 142-179. http://dx.doi. org/10.1108/10662241211214548

Wilkie, W.L. \& Pessemier, E.A., 1973, 'Issues in marketing's use of multi-attribute attitude models', Journal of Marketing Research, 10(4), 428-441. http://dx.doi. attitude models', Journal
org/10.2307/3149391

Wilson, A., Zeithaml, V.A., Bitner, M.J. \& Gremler, D.D., 2012, Services marketing: integrating customer focus across the firm, 2nd European edn., McGraw-Hill, Maidenhead, Berkshire.

Wu, P.C.S. \& Wang, Y.C., 2011, 'The influences of electronic word-of-mouth message appeal and message source credibility on brand attitude', Asia Pacific Journal of Marketing and Logistics, 23(4), 448-472. http://dx.doi. org/10.1108/13555851111165020

Ye, L., Bose, M. \& Pelton, L., 2012, 'Dispelling the collective myth of Chinese consumers: a new generation of brand-conscious individualists', Journal of Consumer Marketing, 29(3), 190-201. http://dx.doi.org/10.1108/07363761211221729 